\title{
Telemedicine system based on ECG signals and in the TCP/IP protocol using a sparse space
}

\author{
Wilmar Tuay¹ / wilmar.tuay@unipamplona.edu.co \\ Luis Mendoza² / luis.mendoza@unipamplona.edu.co \\ Leonor Jaimes Cerveleón³ / leonor.jaimes@unipamplona.edu.co \\ 1,2 Grupo de Ingeniería Biomédica GIBUP, Universidad de Pamplona, Colombia \\ ${ }^{3}$ Grupo de Investigación INGAPO, Universidad de Pamplona, Colombia
}

\begin{abstract}
Telemedicine systems are revolutionizing applications in the health sector, to the point where people are monitored remotely. This article presents a telemedicine system for transmission of electrocardiographic data (ECG) using TCP/IP protocol in real time. The communication system consists of the stage of instrumentation that includes amplifiers and filters. TCP/IP communication system was used to transmit and tele-monitor the subjects. We performed tests with 30 subjects, in addition was determined by the percentage of error of information loss had an average value of $0.25 \%$.
\end{abstract}

KEYWORDS Electrocardiogram, TCP / IP, Tele-monitoring, WLAN.

Sistema de telemedicina basado en señales ECG y protocolo TCP/IP usando un espacio Sparse

RESUMEN Los sistemas de telemedicina vienen revolucionando las aplicaciones en el sector salud, hasta el punto donde las personas son monitoreadas de forma remota. Este artículo presenta un sistema de telemedicina para la transmisión de datos electrocardiográficos [ECG] bajo el protocolo TCP/IP en tiempo real. El sistema de comunicación consta de la etapa de instrumentación que incluye amplificadores y filtros. Se realizó un sistema de comunicación TCP/IP para transmitir y tele-monitorear los sujetos y se realizaron pruebas con treinta individuos. El porcentaje de error de pérdida de información tuvo un valor promedio de $0.25 \%$.

PALABRAS CLAVE Electrocardiograma; protocolo TCP/ IP, Tele-monitoreo, WLAN.
Sistema de tele medicina baseada em sinais ECG e protocolo TCP / IP usando um espaço Sparse

RESUMO Os sistemas de tele medicina estão a revolucionar as aplicações no sector da saúde, até o ponto em que as pessoas são monitoradas remotamente. Este artigo apresenta um sistema de tele medicina para a transmissão de dados eletrocardiográficos [ECG] no âmbito do protocolo TCP / IP em tempo real. O sistema de comunicação consta da etapa de instrumentação, a qual inclui amplificadores e filtros. Foi realizado um sistema de comunicação TCP / IP para transmitir e tele monitorar os sujeitos e foram conduzidos testes com trinta indivíduos. A taxa de erro de perda de informação teve um valor médio de $0,25 \%$.

PALAVRAS-CHAVE Eletrocardiograma; TCP/IP; tele controlo; WLAN. 


\section{Introduction}

The transmission control protocol used together with the IP protocol [TCP/IP] was designed to be utilized as a reliable host-to-host protocol between computers and/or devices in a communication network for packets exchange and used as an interconnected system of those networks (ISI, 1981). This protocol has been very important in the development of the telecommunications worldwide, making possible to integrate several services such as the telemedicine, by taking advantage of its high competitiveness level.

Currently, this protocol is being used for real-time monitoring applications of physiological signals, specifically in diseases affecting the cardiac system. The heart's electric signals combined with the use of the electrocardiogram [ECG] allow the knowing of the cardiac system performance. These signals present a register of all the activity performed by this muscle (the heart) and, through them, it is possible to identify both when the heart is working normally and when a failure is presented. It is important to have a good technological platform when the transmission of these signals is carried on, this seeking security, velocity, but especially precise and no-errors signals.

The TCP/IP protocol is widely used in the Internet. It is the protocol for the transport layer and its usage has been growing in a considerable manner due to the networks intercommunication in the corporative areas. This, given its superior design especially when the Wide Area Networks [WAN] are employed.

The Digital Imaging and Communications in Medicine [DICOM] standard, used for the exchange of medical images employs TCP/IP as its communication protocol (Aparício, Figueroa, Pacheco, \& Silva, 2011). Different studies about the TCP/IP applications in telemedicine have been carried out, among them, we can mention the ones performed by Kho, Saim, \& Soon (2002), Reske \& Moussavi (2002), and Hernández (2003). Most of these studies have been executed to monitor biomedical signals to avoid unnecessary mobilizations and large-size devices, reducing sanitary costs. These research works indicate the need and urgency of the technological inclusion of the telecommunications in the health sector.

In this article, we show the results of the TCP/IP communication, besides the implementation of a register card and acquisition of the ECG signals, which permit the construction of an automatic data measurement and transmission system in real time.

\section{Introducción}

El protocolo de control de transmisión [TCP/IP] está pensado para ser utilizado como un protocolo host a host muy fiable entre miembros de redes de comunicación de computadoras para intercambio de paquetes y en un sistema interconectado de tales redes (ISI, 1981). Este mismo protocolo ha sido indispensable para el desarrollo de las telecomunicaciones en el mundo, que de este modo han hecho factible integrar una variedad de servicios, como es el caso de la telemedicina, aprovechando su alto nivel de compatibilidad.

Actualmente, se está utilizando este protocolo para aplicaciones de monitoreo en tiempo real de señales fisiológicas, específicamente en enfermedades que afectan el sistema cardíaco. Las señales eléctricas del corazón o el empleo de un electrocardiograma [ECG], permiten conocer el comportamiento del sistema cardíaco. Estas señales indican un registro de toda la actividad realizada por este músculo (corazón) y a través de ellas identificar cuándo el corazón funciona normalmente o cuándo existe alguna falla. Al transmitir estas señales es de vital importancia contar con una buena plataforma tecnológica que brinde seguridad, rapidez, pero sobre todo que dicha señal se envíe de manera precisa y libre de errores.

El protocolo de control TCP / IP es muy utilizado en Internet. Es el protocolo para la capa de transporte. Su uso se ha difundido de manera considerable en la intercomunicación de redes en el ámbito empresarial debido a su diseño superior para las Wide Area Network [WAN].

El estándar DICOM [Digital Imaging and Communications in Medicine], utilizado para el intercambio de imágenes médicas, utiliza TCP/IP como su protocolo de comunicación (Aparício, Figueroa, Pacheco, \& Silva, 2011). Diferentes estudios sobre la aplicación del protocolo TCP/IP en telemedicina se han llevado a cabo, entre ellos los de Kho, Saim, y Soon (2002), Reske y Moussavi (2002), y Hernández (2003), la mayoría de ellos se han realizado para monitoreo de señales biomédicas, con el fin de evitar movilizaciones innecesarias y dispositivos de gran tamaño, y disminuir costos sanitarios. Estos trabajos indican la necesidad y la urgencia de la incursión de la tecnología de las telecomunicaciones en el sector salud.

En este articulo se muestran los resultados de la comunicación TCP/IP, además de la implementación de la tarjeta de registro y adquisición de las señal EGG, los cuales permiten tener un sistema automático de medición y transmisión de datos en tiempo real.

\section{Sistema de registro y transmisión de seña-} les

En la Figura 1 se puede observar el diagrama en bloques del sistema a implementar, el cual está diseñado para la adquisición de una derivación DI en un EGG.

\section{A. Registro de la señal}

Para obtener señales electrocardiográficas es necesario analizar las características eléctricas de las señales cardiacas, el tipo de electrodos a usar y su colocación en el cuerpo del pacien- 


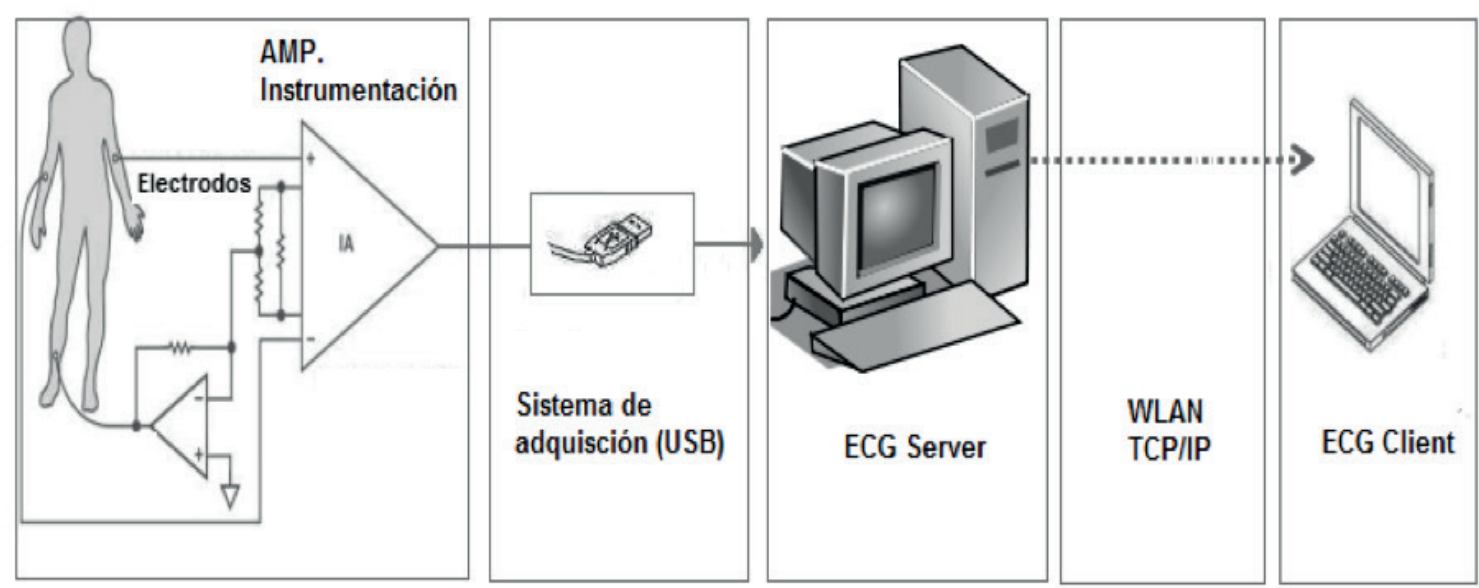

Figure 1. Block diagram of the system / Diagrama de bloques del sistema

te dependiendo del tipo de pruebas (en reposo o en esfuerzo). Para el análisis de las señales del corazón es indispensable comprender los dos tipos de derivaciones cardiacas (bipolares y unipolares), además de su obtención con base en las señales provenientes de los electrodos (Proakis \& Manolakis, 1998).

Las señales ECG se registraron usando cuatro electrodos superficiales de espuma que poseen hidrogel adhesivo, estos se ubicaron en configuración bipolar de la siguiente forma: dos electrodos bipolares en el la región torácica o pectoral y dos electrodos en la región abdominal.

Es así como se obtienen las derivaciones bipolares, también conocidas como lecturas de Einthoven. La salida de estas derivaciones mide el potencial eléctrico de un electrodo comparado con el potencial eléctrico de otro electrodo.

\section{B. Amplificación de la señal}

Las señales cardíacas cuentan con una amplitud extremadamente baja, de alrededor de $5 \mathrm{mV}$, por lo que es necesario el uso de amplificadores especiales. El propósito principal del amplificador es incrementar el nivel de la señal que se obtiene con los electrodos, excluyendo cualquier tipo de interferencia. Para estas señales es necesaria una etapa de amplificación que cumpla con los requerimientos para adquirir biopotenciales, entre ellos tener un alto CMRR y un lazo de realimentación que ayuda a eliminar interferencias provenientes del paciente.

\section{Register and signal transmis- sion system}

In Figure 1, it is possible to observe the block diagram of the system to implement, which is designed for the acquisition of a DI derivation in an EGG.

\section{A. Signal registering}

To obtain electrocardiographic signals, it is necessary to analyze the electric features of the cardiac signals, the electrode type to use, and its allocation in the patient body depending on the test type (rest or effort test). For the analysis of the heart signals, it is essential to understand the two types of cardiac derivations (i.e., bipolar and unipolar ones), besides of their gathering method based on the electrodes signals (Proakis \& Manolakis, 1998).

The ECG signals were recorded using four foam superficial electrodes spread with adhesive hydrogel, these elements were in bipolar configuration as follow: two bipolar electrodes in the thoracic (chest) region and two in the abdominal region.

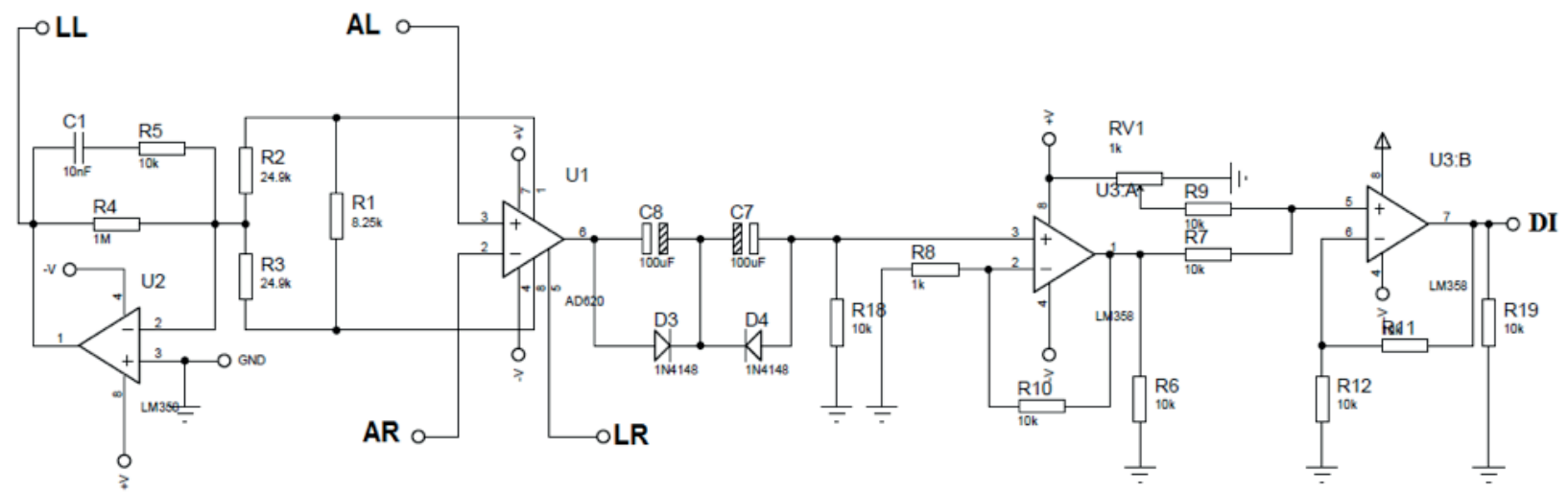

Figure 2. Amplification circuit to measure a bipolar derivation / Circuito de amplificación para medir una derivación bipolar 
The bipolar derivations are obtained using the previous method, these ones are also known as Einthoven lectures. The exit of these derivations measure the electric potential of another electrode.

\section{B. Signal amplification}

The heart signals have an extremely low amplitude, i.e., around $5 \mathrm{mV}$. For this reason, the use of special amplifiers is a must-have. The main proposal of these devices is to increase the signal level arriving from the electrodes but excluding any interference. For this, an amplification stage meeting all the requirements to acquire biopotentials is required. Biopotentials such as having a high CMRR and a feedback loop to eliminate interferences coming from the patient are important.

To fulfill these requirements, we used an AD620 instrumentation amplifier of the Analog Device brand. This AD620 device requires only a few elements to operate; nevertheless, it presents some instability when the amplification of heart signals in factors greater than 70 is performed. For this reason, the need to amplify the signal obtained from the AD620 with another device is requested; this device is the LM358 operational amplifier configured to use its adder and cascade non-inverter configurations. FiguRE 2 presents the amplifier circuit for a bipolar derivation.

\section{Signal digitalization and gathering}

For the discretization of the signal coming from the ECG derivation, we employed a hardware component (A/D internal converter of the $18 \mathrm{~F} 2550 \mathrm{PIC}$ ) and a software component in charge of controlling the A/D converter. The selected routine was written in the $\mathrm{C}$ programming language and it was compiled using the PIC C Compiler. We used the 18F2550 PIC because it has an embedded A/D converter and it also has an interface for a USB port.

Once the digitalization of the signal is completed, the gathering from the PC was performed through the data acquisition card as a central element. This card has the necessary features and it complies the requirements of an input channel (pin number 2: AN0) and a communication module with the PC through the USB port (pins 15 and 16). Practically, the PIC does not require external components, except the necessaries to implement the $20 \mathrm{MHz}$ clock and decoupling capacitors.

\section{Sparse conversion}

We performed a sparse conversion using the direct cosine transform by employing the L1 norm to measure sparsity and we noticed that it achieved better results than the Fourier
Para cumplir con estos requisitos se utilizó un amplificador de instrumentación AD620 de la firma Analog Device. El AD620 requiere de muy pocos elementos para funcionar, sin embargo muestra inestabilidad al tratar de amplificar las señales cardíacas en factores mayores a 70, es por eso que surge la necesidad de amplificar la señal obtenida de este con el amplificador operacional LM358, en configuración de sumador y amplificador no inversor en cascada. En la Figura 2 se muestra el circuito amplificador para una derivación bipolar.

\section{Digitalización y adquisición de la señal}

Para la discretización de la señal proveniente de la derivación del ECG se utilizó una componente hardware (conversor A/D interno del PIC 18F2550) y una componente software, que es la rutina encargada de dirigir el funcionamiento del Conversor A/D. La rutina señalada se escribe en el lenguaje de programación $\mathrm{C}$, utilizando PIC C Compliler. Se usó el PIC 18F2550 debido a que, entre sus ventajas, incluye conversor A/D y una interface al puerto USB.

Una vez digitalizada la señal, se realizó la adquisición desde la PC, a través de la tarjeta de adquisición de datos como elemento central. Esta tarjeta cuenta con las características necesarias, ya que se requiere de un canal de entrada analógico (pin 2 AN0) y un modulo de comunicación con la PC a través del puerto USB, que se efectúa en forma directa mediante los pines 15 y 16 del mismo. Prácticamente el PIC no requiere componentes externos, excepto los necesarios para implementar el reloj de $20 \mathrm{MHz}$ y capacitores de desacople.

\section{Conversión sparse}

Se realizó una conversión sparse usando la transformada discreta del coseno, se utilizó la norma L1, para medir sparsidad, se evidenció que permite mejores resultados que la transformada de Fourier, los factores de sparsidad presentados por Fourier fueron 45.24 y de discreta del coseno fueron 13.65. Esto concluye que, para un proceso de reconstrucción, es mejor el coseno de Fourier. En este artículo se realiza el proceso de reconstrucción y no de compresión usando compressive sensing, en un futuro se pretende demostrar que se puede implementar un sistema de telemedicina basado en CS.

\section{E. Transmisión de datos mediante TCP/IP}

La arquitectura implementada para la transmisión ECG es una configuración cliente-servidor y está compuesta de tres fases: transmisión, interfaz de acceso y recepción. La Figura 3 muestra, a manera de diagrama pictórico, esta arquitectura. A continuación se describen cada una de estas fases.
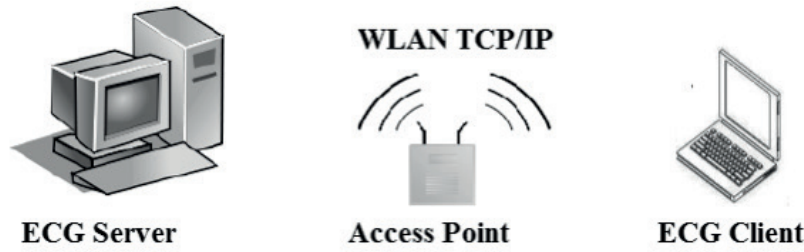

Figure 3. TCP/P transmission architecture / Arquitectura de transmisión TCP/IP 


\section{Transmisor (servidor ECG)}

En este nodo se realiza el censado de la señal de ECG y se preparan los paquetes a transmitir. El programa fuente que realiza estas operaciones y controla el nodo es un código desarrollado en Matlab, el cual utiliza, como base, la caja de control de instrumentos que le permite a Matlab conectar instrumentos periféricos como: osciloscopios, generadores de funciones, analizadores de señales, fuentes de alimentación e instrumentos analíticos. Además, la caja de herramientas de control de instrumentos soporta protocolos de comunicación como TCP/IP para secciones Matlab que se encuentren en la misma red. La interfaz gráfica del servidor se diseñó en Matlab (Figura 4).

Las pruebas realizadas se han simulado con un algoritmo generador de señales EGG, para que así, cuando se haga el respectivo acople del sistema, no se tengan problemas en el momento de la transmisión.

\section{Interfaz de acceso (WLAN)}

La comunicación se implementó en una Red de Área Local [LAN], a través de un punto de acceso, con el propósito de darle una mayor cobertura. Para la plataforma de comunicación se tuvo en cuenta a las redes Wi-Fi, ya que ofrecen beneficios como: movilidad, flexibilidad, escalabilidad y velocidades que van desde $1 \mathrm{Mbps}$ (802.11) hasta $150 \mathrm{Mbps}(802.11 \mathrm{n})$, las que serán de bastante relevancia a la hora de implementar este sistema en interiores, como puestos de salud.

\section{Recepción (cliente ECG)}

El nodo del lado del cliente es el que ejecuta la recepción adecuada de los paquetes provenientes del servidor EGG. El código fuente especializado en hacer la recepción se desarrolló en Matlab. Para poder visualizar los datos del ECG se implementó una réplica de la interfaz grafica del lado del cliente, lo cual permite leer paquetes de datos desde un puerto de conexión, es decir que asocia un puerto de comunicación a un puerto TCP concreto. Una vez obtenidos los paquetes, se hace el despliegue del ECG y ciertas

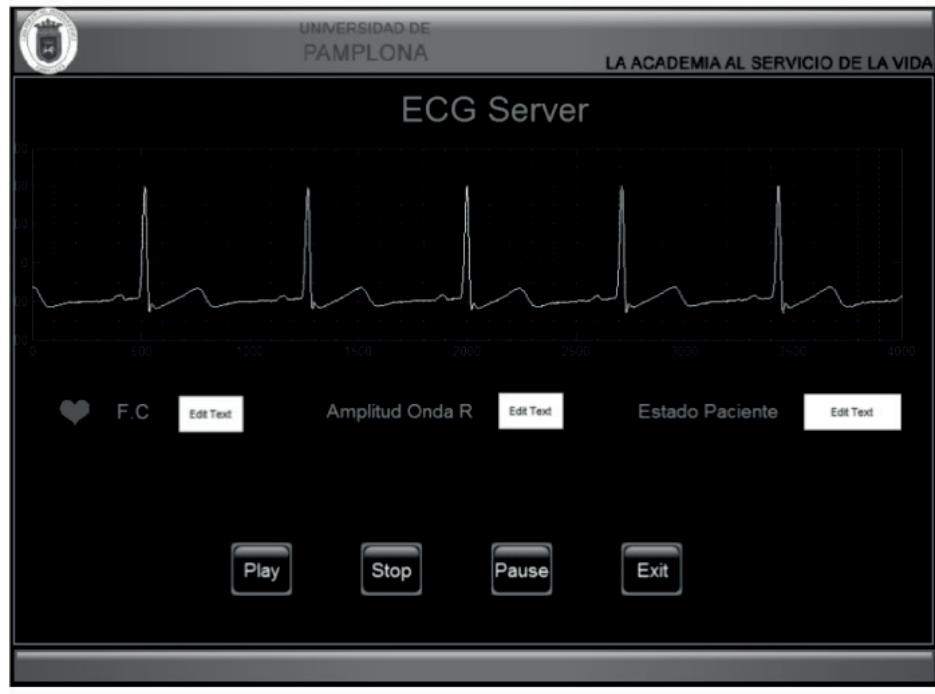

Figure 4. Graphical interface of the server / Interfaz gráfica del servidor transform where the sparsity factor in the Fourier one was 45.24; while using the cosine, the obtained result was 13.65 . Summarizing, the cosine transform is more adequate for reconstruction processes. In this article, we performed the reconstruction process (and not the compression) using compressive sensing and in the future, we plan to demonstrate that it is possible to implement a telemedicine system based on CS.

\section{E. Data transmission through TCP/P}

The implemented architecture for the ECG transmission is a client-server configuration and it has three stages: transmission, access interface, and reception. FIGURE 3 shows this architecture in a pictorial diagram and after it, we discuss each of these stages.

\section{Transmitter (ECG server)}

In this node, the sensing of the ECG signal is performed and the packets to transmit are prepared. The source program performing these operations and controlling the node is a code developed in MATLAB, which uses the instruments toolbox as its basis. This allows MATLAB to connect peripheral instruments such as oscilloscopes, function generators, signal analyzers, power sources, and analytic instruments. Further, the instruments toolbox supports communication protocols such as TCP/IP for MATLAB sections within the same network. The graphical interface of the server was also designed in MATLAB (see Figure 4).

The performed tests were simulated with an algorithm generating ECG signals; hence, when the coupling of the system is carried out, no issues would appear in the transmission moment.

\section{Access interface (WLAN)}

The communication was implemented in a Local Area Network [LAN] through an access point; this, seeking a broader coverage. For the communication platform, we considered the Wi-Fi networks, since they offer benefits such as: mobility, flexibility, scalability, and speeds from $1 \mathrm{Mbps}$ (802.11) up to $150 \mathrm{Mbps}$ (802.1 1n). This will be useful if the implementation of the proposed system is performed in indoor environments, such as hospitals.

\section{Reception (ECG client)}

The node in the client side is the one executing the reception of the packets coming from the ECG server. The specialized source code to perform this was also developed in MATLAB. To visualize the ECG data, 
we implemented a replica of the graphical interface in the client side. This allows to read the data packets from a singular connection port, i.e., the system associates a communication port to a concrete TCP port. Once the packets are obtained, the deployment of the ECG is carried out together with certain features of it such as: heart rate, amplitude of the $\mathrm{R}$ wave, and connection state of the patient.

\section{Results}

The transmission algorithms were implemented using the TCP/IP protocol in real time. Figure $\mathbf{5}$ shows a signal received in the transmission process. The reader might note that it conserves the usual features in an ECG signal.

It is important to mention that, in a future work, we plan to perform the analysis in the signal morphology, in this moment, a result in the amount of information lost in the transmission processes is available. We carried out 57 transmissions in real time coming from 13 different patients.

The structure of the register and acquisition card for ECG signals is showed in FiguRE 6. This card oversees performing the signal acquisition, including its amplification and filtering. It has a size of $10 \times 12 \mathrm{~cm} 2$. This design can be understandable as a portable and Holter system at the same time.

TABLE 1 shows the transmission results of the information for 1,000 points regarding sending times. Here, the reader can observer that the times have around $9.87 \mathrm{~ms}$ of delay, time not relevant for telemedicine applications.

Finally, it is relevant to mention that the average transmission error of the subjects had a magnitude of $0.25 \%$; hence, the information loss was about $2.13 \%$.

\section{Conclusions}

The conversion to a sparse signal allows the more efficient processing of the signals; this new signal is less dense and, hence, with higher energy compaction percentage than the original one. This implies that the discrete cosine transform allowed the obtaining of a signal with high sparsity level.

The TCP/IP protocol is useful for real-time transmission applications, it is essential for telemedicine applications and

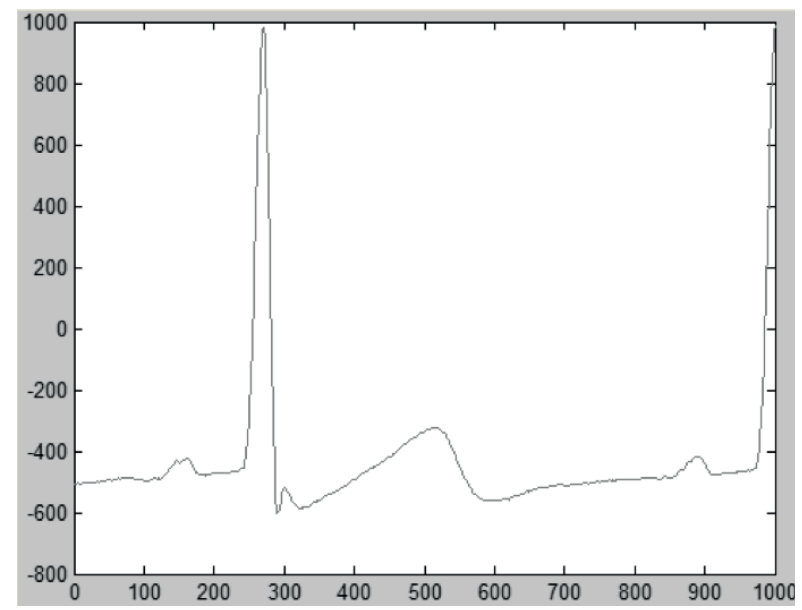

Figure 5. Transmitted signal / Señal transmitida

características del mismo, como son: frecuencia cardiaca, amplitud de la onda $\mathrm{R}$ y estado de conexión del paciente.

\section{Resultados}

Los algoritmos de transmisión, fueron implementados utilizando el protocolo TCP/IP en tiempo real. LA FiguRA 5 muestra una señal recibida en el proceso de transmisión, nótese que ella conserva las características usuales de una onda ECG.

Es importante mencionar que en un trabajo futuro se realizará el análisis sobre la morfología de la señal, en este momento se tiene un resultado de cantidad de información perdida en el procesos de transmisión. Se realizaron 57 transmisiones en tiempo real provenientes de trece pacientes diferentes.

La estructura de la tarjeta de registro y adquisición de señales ECG, que se muestra en la Figura 6, es la encargada de realizar la adquisición de la señal, incluyendo su amplificación y filtrado. Es una tarjeta de tamaño de $10^{*} 12 \mathrm{~cm} 2$. Esta diseño puede entenderse como un sistema portable y Holter a la vez.

La TABla 1 muestra los resultados de transmisión de información por 1000 puntos, en cuanto a tiempos de envío. Aquí se evidencia que los tiempos oscilan alrededor de 9,87 milisegundos de retardo, tiempo que no es significativo para aplicaciones de telemedicina.

Finalmente, es importante mencionar que el error de transmisión promedio de los sujetos tuvo una magnitud de $0.25 \%$, por lo que se concluye una pérdida de información del 2.13\%.

Table 1. Transmission results of a 1,000-point ECG signal / Resultados de transmisión de una señal ECG de 1000 puntos

\begin{tabular}{ll}
\hline Server & \\
\hline Data to transmit / Datos a Tx & ECG signal \\
Length / Longitud & 1,000 positions \\
Size (Bytes) / Tamaño & 8,000 \\
Execution time / Tiempo de ejecución & 0.847752 seconds \\
\hline
\end{tabular}

\begin{tabular}{ll}
\hline Client & \\
\hline Data to transmit / Datos a Tx & ECG signal \\
Length / Longitud & 1,000 positions \\
Size (Bytes) / Tamaño & 8,000 \\
Delay time / Tiempo de retardo & $9.87 \mathrm{~ms}$ \\
\hline
\end{tabular}




\section{Conclusiones}

La conversión a una señal sparse permite procesar la señal de manera más eficiente, por ser una señal poco densa y, por ende, con mayor porcentaje de compactación de la energía que la señal original. Esto indica que la transformada discreta del coseno permitió obtener una señal con alto de grado de sparsidad.

El protocolo TCP/IP es muy útil para aplicaciones de transmisión de datos en tiempo real, es fundamental para aplicaciones de telemedicina y puede servir para llevar a cabo aplicaciones de tele-monitoreo de parámetros de señales fisiológicas de manera adecuada.

La unificación del sistema de instrumentación, el sistema de digitalización y la transmisión de información fue fundamental ya que se logró tener un sistema (por ahora) de tele-monitoreo de señales ECG, que permitirá, a futuro, realizar parametrización de las señales ECG y tener un sis-

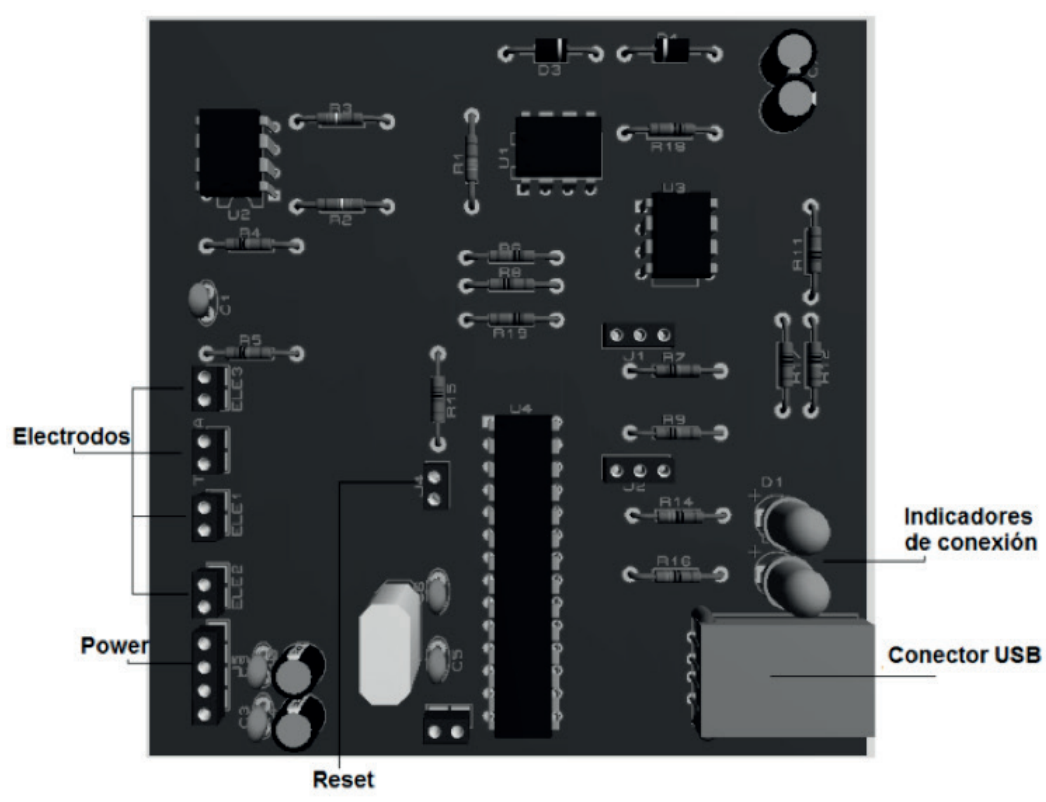
tema de tele-monitoreo de parámetro como: ritmo cariaco $\mathrm{y}$ amplitud onda $\mathrm{R}$ entre otras.

El sistema presentado en este artículo es novedoso en cuanto a su aplicación de tele-monitoreo en tiempo real de señales ECG, cuya implementación, en la actualidad, es necesaria en muchos centros de salud, para así permitir un más eficiente control de pacientes en ambientes normales y la toma de decisiones rápidas respecto de personas con problemas del sistema cardíaco. $\mathbf{S} T$

Figure 6. Simulation of the register and acquisition card / Simulación de tarjeta de adquisición y registro

it might be useful to perform telemonitoring applications in physiologic signals parameters more accurately.

The unification of the instrumentation system, the digitalization one, and the information transmission was essential, since we achieved to build (for now) a telemonitoring system of ECG signals that will allow - in the future - the parametrization of these signals and the monitoring of parameters such as heart rate and R-wave amplitude, among others.

The presented system in this article is a novel one, since its application in real time telemonitoring of ECG signals is necessary in the hospitals and health centers. The implementations of systems such as ours is essential to allow a more efficient patient control in normal environments and ease the fast decision-making process regarding people with heart diseases. Sat 


\section{References / Referencias}

Aparício, G., Figueroa, B., Pacheco, A., \& Silva, M. (2011). Tecnologías en salud. Volumen 3. Telemedicina. México: Secretaría de Salud.

Hernández A. (2003). Electrocardiógrafo para pruebas en esfuerzo basado en instrumentación virtual [tesis]. Oaxaca, México: Universidad Tecnológica de la Mixteca.

Information Sciences Institute [ISI]. (1981). Transmission control protocol. Arlington, VA: Darpa.

Kho, Y. Y., Saim, H. B., \& Soon, C. F. (2002). Remote monitoring of vital physiological signs. In Research and Development, 2002. SCOReD 2002. Student Conference on (pp. 69-71). IEEE.

Proakis, J. \& Manolakis, D. (1998). Tratamiento digital de señales. Madrid, España: Prentice Hall.

Reske, D., \& Moussavi, Z. (2002, October). Design of a web-based remote heart-monitoring system. In Engineering in Medicine and Biology, 2002. 24th Annual Conference and the Annual Fall Meeting of the Biomedical Engineering Society EMBS/BMES Conference, 2002. Proceedings of the Second Joint (Vol. 3, pp.1847-1848). IEEE. 


\section{CURRICULUM VITAE}

Wilmar Tuay Engineer in Telecommunications from the Universidad de Pamplona (Colombia). He worked with the Corporación Centro de Ciencia y Tecnología de Antioquia / Ingeniero en Telecomunicaciones de la Universidad De Pamplona (Colombia). Trabajó con la Corporación Centro de Ciencia y Tecnología de Antioquia.

Luis Enrique Mendoza Engineer in Telecommunications from the Universidad de Pamplona (Colombia). He worked with the Corporación Centro de Ciencia y Tecnología de Antioquia / Ingeniero en Telecomunicaciones de la Universidad De Pamplona (Colombia). Trabajó con la Corporación Centro de Ciencia y Tecnología de Antioquia.

Leonor Jaimes Cerveleón Industrial Engineer and Specialist in Integrated Systems for Quality Management from Universidad de Pamplona and Master in Business Administration and Innovation form Universidad Simon Bolivar / Ingeniera Industrial con Especialización en Sistemas Integrados de Gestión de Calidad de la Universidad de Pamplona y Maestría en Administración de Empresas e Innovación, de la Universidad Simón Bolívar. 